\title{
Current and novel renal biomarkers in heart failure
}

\author{
Kevin Damman • Adriaan A. Voors • \\ Gerjan Navis • Dirk J. van Veldhuisen • \\ Hans L. Hillege
}

Published online: 22 May 2011

(C) The Author(s) 2011. This article is published with open access at Springerlink.com

\begin{abstract}
Renal function is the most important predictor of clinical outcome in heart failure (HF). It is therefore essential to have accurate and reliable measurement of renal function and early specific markers of renal impairment in patients with HF. Several renal functional entities exist, including glomerular filtration (GFR), glomerular permeability, tubulointerstitial damage, and endocrine function. Different markers have been studied that can be used to determine changes and the effect of treatment in these entities. In the present review, we summarize current and novel markers that give an assessment of renal function and prognosis in the setting of acute and chronic HF.
\end{abstract}

Keywords Renal function - Heart failure - Glomerular filtration rate $\cdot \mathrm{gfr} \cdot$ Albuminuria $\cdot$ Tubular damage . Cystatin $\mathrm{C} \cdot N$-acetyl-beta-D-glucosaminidase $\cdot$ Kidney injury molecule $1 \cdot$ Neutrophil gelatinase-associated lipocalin · FABP · Interleukin $18 \cdot \mathrm{IL}-18 \cdot \operatorname{mdrd} \cdot$ NAG $\cdot$ KIM-1 $\cdot$ NGAL

\footnotetext{
K. Damman $(\varangle)$ - A. A. Voors · D. J. van Veldhuisen · H. L. Hillege

Department of Cardiology, University Medical Center Groningen, University of Groningen, Hanzeplein 1, 9700 RB Groningen, The Netherlands

e-mail: k.damman@thorax.umcg.nl

\section{G. Navis}

Department of Nephrology, University Medical Center Groningen, University of Groningen, Hanzeplein 1, 9700 RB Groningen, The Netherlands
}

\section{H. L. Hillege}

Department of Epidemiology, University Medical Center Groningen, University of Groningen, Hanzeplein 1, 9700 RB Groningen, The Netherlands

\section{Introduction}

In patients with heart failure (HF), impaired renal function is often present and one of the strongest predictors of clinical outcome [1-4]. Both worsening renal function (WRF) and acute kidney injury (AKI) are prevalent in patients with acute and chronic $\mathrm{HF}$ and are associated with an increased mortality and morbidity $[1,5,6]$. In addition, renal dysfunction might not only be a marker of a poor clinical condition, but might also contribute to the development and progression of heart failure [7]. Renal function and changes in renal function therefore provide important clinical information in patients with HF.

Usually, "renal function" is defined as the filtration ability of the kidney, which can be expressed as the glomerular filtration rate (GFR). Creatinine and empirical formulas that are mainly based on creatinine are used to estimate GFR in patients with HF [8]. However, GFR does not cover the entire function of the kidney, which also comprises of glomerular permeability, tubular function, and several specific functions such as vitamin D metabolism and erythropoietin production. Therefore, several markers other than creatinine can be used to estimate various functions of the kidney.

In the present review, we summarize current and novel promising markers/ways to assess renal function and changes in renal function in patients with $\mathrm{HF}$ and their prognostic potential in HF. We will focus on glomerular function, glomerular permeability, and tubulointerstitial damage. Table 1 gives an overview of the clinical characteristics of the markers that will be discussed in the present review.

\section{Glomerular filtration rate}

The golden standard of measuring GFR is by specific markers such as iothalamate or inulin clearance. These 
Table 1 Properties of different markers

\begin{tabular}{|c|c|c|c|c|c|}
\hline & Detection & "Validation" & Relation with prognosis & Pro's & Cons \\
\hline \multicolumn{6}{|c|}{ Glomerular filtration rate } \\
\hline Creatinine & Serum $^{a}$ & $\begin{array}{l}\mathrm{CHF} \\
\mathrm{AHF}\end{array}$ & Strong evidence & $\begin{array}{l}\text { Easy } \\
\text { Cheap } \\
\text { Interpretable }\end{array}$ & $\begin{array}{l}\text { Exponential relationship with GFR } \\
\text { Dependent on muscle mass }\end{array}$ \\
\hline (s)MDRD & Serum & $\begin{array}{l}\text { CHF } \\
\text { Not in AHF }\end{array}$ & Strong evidence & $\begin{array}{l}\text { Valid } \\
\text { Accurate }\end{array}$ & $\begin{array}{l}\text { Formula (calculation) } \\
\text { Less reliable in extremes of GFR }\end{array}$ \\
\hline BUN & Serum & $\begin{array}{l}\mathrm{CHF} \\
\mathrm{AHF}\end{array}$ & Emerging evidence & $\begin{array}{l}\text { Easy } \\
\text { Cheap }\end{array}$ & Interpretation difficult \\
\hline Cystatin C & Serum $^{a}$ & $\begin{array}{l}\text { CHF } \\
\text { AHF }\end{array}$ & Evidence in $\mathrm{AHF}$ & $\begin{array}{l}\text { Unbiased } \\
\text { Very reliable }\end{array}$ & $\begin{array}{l}\text { Interpretation difficult } \\
\text { Costs }\end{array}$ \\
\hline \multicolumn{6}{|c|}{ Glomerular permeability } \\
\hline Albuminuria & Urine & $\begin{array}{l}\mathrm{CHF} \\
\text { Not in } \mathrm{AHF}\end{array}$ & Strong evidence $\mathrm{CHF}$ & $\begin{array}{l}\text { Easy obtainable } \\
\text { Cheap } \\
\text { Additive to GFR }\end{array}$ & Low specificity \\
\hline \multicolumn{6}{|c|}{ Tubulointerstitial damage } \\
\hline NAG & Urine & $\begin{array}{l}\mathrm{CHF} \\
\text { Not in AHF }\end{array}$ & Emerging evidence $\mathrm{CHF}$ & $\begin{array}{l}\text { Easy obtainable } \\
\text { Additive to GFR and } \\
\text { UAE } \\
\text { Strong marker of AKI }\end{array}$ & $\begin{array}{l}\text { Low specificity } \\
\text { Costs }\end{array}$ \\
\hline KIM-1 & Urine & $\begin{array}{l}\text { CHF } \\
\text { Not in AHF }\end{array}$ & Emerging evidence $\mathrm{CHF}$ & $\begin{array}{l}\text { Easy obtainable } \\
\text { Additive to GFR and } \\
\text { UAE } \\
\text { Strong marker of AKI }\end{array}$ & Costs \\
\hline NGAL & $\begin{array}{l}\text { Urine/ } \\
\text { Serum }\end{array}$ & $\begin{array}{l}\mathrm{CHF} \\
\mathrm{AHF}\end{array}$ & $\begin{array}{l}\text { Emerging evidence } \mathrm{CHF} \\
\text { and } \mathrm{AHF}\end{array}$ & $\begin{array}{l}\text { Easy obtainable } \\
\text { Additive to GFR and } \\
\text { UAE } \\
\text { Strong marker of AKI }\end{array}$ & $\begin{array}{l}\text { Low specificity especially in serum } \\
\text { and in CHF }\end{array}$ \\
\hline IL-18 & $\begin{array}{l}\text { Urine/ } \\
\text { Serum }\end{array}$ & $\begin{array}{l}\mathrm{CHF} \\
\text { Not in } \mathrm{AHF}\end{array}$ & Emerging evidence $\mathrm{CHF}$ & $\begin{array}{l}\text { Easy obtainable } \\
\text { Strong marker of AKI }\end{array}$ & $\begin{array}{l}\text { Also strongly increased } \\
\text { in inflammation }\end{array}$ \\
\hline FABP-1 & $\begin{array}{l}\text { Urine/ } \\
\text { Serum }\end{array}$ & $\begin{array}{l}\text { Not in CHF } \\
\text { Not in AHF }\end{array}$ & None & Strong marker of AKI & $\begin{array}{l}\text { Elevated in sepsis } \\
\text { Also found in liver }\end{array}$ \\
\hline
\end{tabular}

$A H F$ acute heart failure, $A K I$ acute kidney injury, $B U N$ blood urea nitrogen, $C H F$ chronic heart failure, $F A B P$ fatty acid binding protein, GFR glomerular filtration rate, $I L-18$ Interleukin 18, KIM-1 kidney injury molecule 1, MDRD modification of diet in renal disease (formula), $N A G N$-acetyl-beta-D-glucosaminidase, $N G A L$ neutrophil gelatinase-associated lipocalin, $U A E$ urinary albumin excretion

${ }^{\text {a }}$ Can be measured in urine, but then does not resemble GFR

measurements are, however, patient-unfriendly, time consuming and expensive and can, therefore, not be used in daily clinical practice. In study cohorts, these techniques have been used to validate easier estimations of GFR, mostly in patients with chronic HF $[8,9]$. Instead, different markers that give an estimate of GFR are used as surrogate markers for GFR.

\section{Serum creatinine}

Creatinine is a break down product of creatine phosphate, which is normally formed at a constant rate in the skeletal muscles. Upon presentation in the plasma, it is freely filtered through the glomerulus and appears in the urine. Creatinine is, however, also actively secreted in the tubules and accordingly its clearance overestimates true GFR to a varying extent [10].

Increased serum creatinine is a common finding in patients with acute and chronic HF and is a sign of renal impairment. In large cohort studies and substudies of randomized clinical trials, an increased serum creatinine level was strongly associated with impaired clinical outcome $[11,12]$. However, serum creatinine levels are prone to bias due to several shortcomings. First, the production of creatine phosphate is not constant. Due to changes in muscle 
mass, when wasting of muscles occurs with progression of cardiac disease, changes in serum creatinine levels may develop, which are not due to changes in GFR. The other way round, a decrease in GFR may go unnoticed when it is accompanied by muscle wasting, which is common in severely and chronically ill patients, including HF patients [8]. Second, serum creatinine shows an exponential relationship with invasively determined GFR. This exponential relationship makes interpretation of changes in serum creatinine difficult (Fig. 1) [13]. Finally, active secretion of creatinine significantly hampers the interpretation of serum creatinine, especially when renal function is compromised, or in obese subjects, when the relative effect of active secretion is most pronounced [14]. Importantly, serum creatinine may be a good representative of the number of functionally active nephron units. Serum creatinine may, therefore, be a reasonable estimate of renal function at one point in time and a strong risk marker, but with significant shortcomings for accurate assessment of GFR. Finally, creatinine clearance may be used to estimate GFR. However, the overestimation due to tubular secretion of creatinine, and urine collection errors, render it unreliable, although novel methods to correct for this may lead to reappraisal of 24-h urine collection [15].
Estimated GFR, creatinine-based formulas

To overcome the problems that may arise with the use of serum creatinine or creatinine clearance, as an estimate of GFR, large (sub) studies have generated empirical formulas that give a more reliable estimation of GFR based on serum creatinine [13]. In addition to serum creatinine, they typically include age and gender, and sometimes weight, race, blood urea nitrogen, and albumin. The most common formulas are the Cockcroft-Gault equation, which is an estimate of creatinine clearance, and the currently widely used (simplified) Modification of Diet in Renal Disease (sMDRD/MDRD) formulas [13]. These formulas have been validated in renal disease, and give a reasonably accurate estimation of GFR, especially in patients with chronic kidney disease and renal function impairment. More recently, these formulas have been validated in patients with chronic HF [8]. Smilde et al. showed that in patients with relatively preserved renal function, the 6-variable MDRD formula showed the most accurate estimation of GFR, with similar prognostic information compared to real GFR [8]. However, all formulas, including Cockcroft-Gault and (s)MDRD overestimate real GFR in the lower levels of true GFR and underestimated real

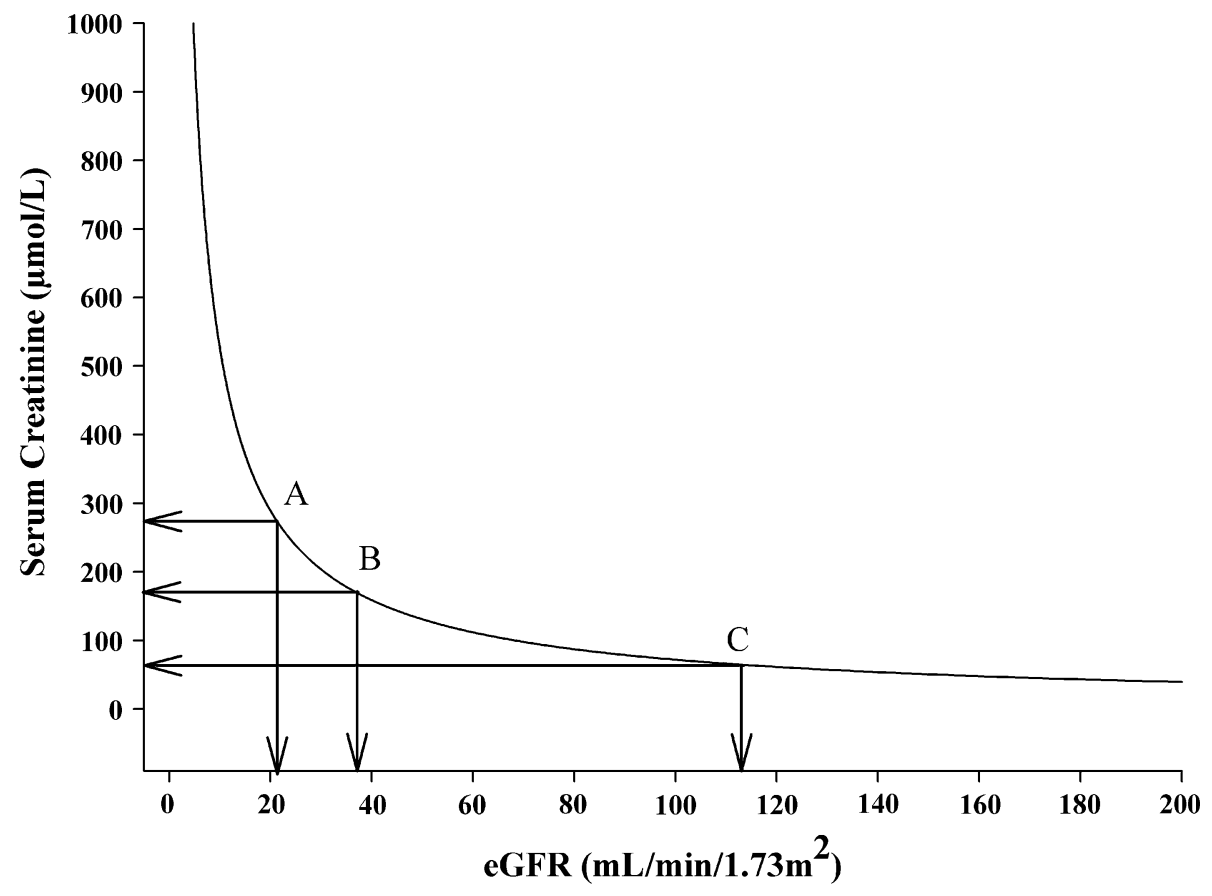

Fig. 1 Relationship between serum creatinine and estimated GFR: effect of change in serum creatinine. Different changes in estimated GFR with similar changes in serum creatinine. A pronounced decrease in GFR from normal-the flat part of the curve-gives just a subtle increase in serum creatinine that often stays within the normal day-to-day variability of the assay and, therefore, may go unnoticed. The other way round, a trivial further decrease in already compromised GFR leads to a steep rise of creatinine, based on the steepness of the curve here, that can lead to undue concern. For example, a decrease in serum creatinine from point $A$ to $B$ results in a decrease in eGFR of $15 \mathrm{ml} / \mathrm{min} / 1.73 \mathrm{~m}^{2}$. However, a decrease in serum creatinine from point $B$ to $C$ results in a much more pronounced decrease in eGFR of $75 \mathrm{ml} / \mathrm{min} / 1.73 \mathrm{~m}^{2}$. Depicted is the GFR estimated by the simplified MDRD for a 70-year-old white male 
GFR in the higher levels of true GFR. Accordingly, in clinical practice, when GFR decreases over a longer period of time, the decrease will be underestimated by these equations. Nevertheless, in numerous studies, both acute and CHF showed that GFR as estimated by these formulas (mostly sMDRD) is an important prognostic factor [2, 8, $16,17]$. Recently, to account for the poor performance of the MDRD equation in the (near) normal and higher ranges of GFR, a new equation, the CKD-EPI equation was developed. It is now considered the preferred estimate of GFR in renal disease. This formula is similar to the MDRD but has creatinine-dependent gender differences and generates higher eGFR at lower creatinine levels. It has a better performance in subjects with normal or near-normal renal function, but this equation has not yet been validated in HF [18]. Given the fact that invasive determination of GFR is expensive and time consuming, to date, the MDRD formula is currently considered the golden standard of estimation of GFR in clinical practice.

Blood urea nitrogen (BUN)

BUN, a waste product of protein catabolism, has been extensively studied in dialysis patients and is an important target for removal by (hemo) dialysis, as well as a marker for the effectiveness of dialysis. Although most clinicians will use BUN with or without serum creatinine in daily practice, only in recent years, the relationship of BUN with outcome in cohorts of patients with HF has been established (Table 2). In large cohorts of patients with acute and chronic HF, an elevated BUN has been shown to be a strong predictor of morbidity and mortality [19-26]. BUN was an even better predictor of outcome compared to GFR in the OPTIME-CHF population [27]. It has been argued that BUN is much more than a reflection of GFR [28]. It is also largely dependent on protein intake, catabolism, and tubular reabsorption. The latter is coupled to sodium reabsorption and may, therefore, reflect the extent of forward failure. Together, BUN or urea may be a reflection of both GFR and of the severity of HF, whereas there is also clear cut impact of nutritional status and catabolic state. This may be the reason why it possesses strong predictive abilities, but in terms of estimation of renal function, and the effect of possible treatment on renal function, BUN may be a more varying and, therefore, unreliable marker compared to creatinine and creatinine-based formulas.

\section{Cystatin C}

Of all markers that give an estimate of GFR, cystatin $\mathrm{C}$ is the newest, although first reports on cystatin $\mathrm{C}$ were already published 30 years ago. Cystatin $C$ is freely filtered through the glomerulus and completely reabsorbed and degraded in the tubulus. Its level in the circulation is therefore an ideal marker of GFR [29]. Cystatin C has been shown to be superior to serum creatinine as an estimate of GFR in several different patient populations, in particular, in the near-normal, normal and higher range, where creatinine-derived measures perform poorly [30]. It is a strong predictor of outcome in coronary artery disease, diabetes, but also the general (elderly) population [31-33]. Data on cystatin $\mathrm{C}$ in chronic and acute $\mathrm{HF}$ are scarce, but some studies have shown the prognostic power of cystatin $\mathrm{C}$ in CHF $[33,34]$. In acute HF, cystatin C showed independent prognostic information, even in patients with normal serum creatinine [35].

However, in HF, no data exist on the reliability of cystatin $\mathrm{C}$ to accurately estimate GFR. In renal disease, cystatin $\mathrm{C}$ has been shown to provide a reliable and less biased estimate of GFR compared to serum creatinine [3638]. Cystatin $\mathrm{C}$ is not influenced by body mass, muscle turnover, and cachexia, which are important confounders of serum creatinine [39]. There have been concerns that cystatin $\mathrm{C}$ may be dependent on inflammatory status or smoking, but others have reported no bias by these factors [32, 40, 41]. Cystatin C levels may be used alone or in a formula similar to creatinine-based formulas, but in each circumstance give accurate estimation of GFR, although

Table 2 Relationship between blood urea nitrogen and outcome in heart failure studies

\begin{tabular}{llllll}
\hline Study & Year & $N$ & Setting & BUN (mg/dL) & Relative risk for mortality \\
\hline Lee [25] & 2003 & 4031 & ADHF & $29 \pm 19$ & $1.49(1.39-1.60)$ per 10 units increase \\
Aronson [19] & 2004 & 541 & ADHF & $34 \pm 22$ & $2.3(1.3-4.1)$ for quartiles \\
Heywood [24] & 2005 & 680 & CHF & $29 \pm 20$ & BUN 30-50: 1.9, BUN $>50: 2.2$ \\
Shenkman [26] & 2007 & 257 & ADHF & $33 \pm 22$ & $3.6(1.8-7.3)$ per log unit increase \\
Filippatos [21] & 2007 & 302 & ADHF & $31 \pm 17$ & $1.03(1.00-1.05)$ per unit increase \\
Cauthen [20] & 2008 & 444 & CHF & $14(6-22)$ & $1.04(1.03-1.06)$ per unit increase \\
Klein [27] & 2008 & 949 & CHF & $25(14-41)$ & $1.11(1.07-1.15)$ per 5 units increase \\
Lin [22] & 2009 & 243 & CHF & $27 \pm 17$ & $1.24(1.02-1.51)$ for BUN-to-creatinine ratio \\
Gotsman [23] & 2010 & 362 & ADHF & $23(17-29)$ & $1.80(1.30-2.49)$, per tertile BUN/creatinine
\end{tabular}

$A D H F$ Acute decompensated heart failure, $B U N$ Blood urea nitrogen, $C H F$ Chronic heart failure 
not always superior to creatinine [36, 38]. Whether cystatin $\mathrm{C}$ may give more reliable estimations of changes in GFR compared to serum creatinine is unknown. From a physiologic perspective, given the totally free filtration through the glomerulus and total degradation in the tubulus, it is likely that it may be a more accurate marker of changes in renal function compared to creatinine [39].

Although cystatin $C$ seems to be superior to creatinine in estimating GFR and may be at least identical to creatinine in establishing prognosis, it is far underused in clinical practice. There are two important reasons and disadvantages of cystatin $\mathrm{C}$ to explain this. First, serum creatinine has been around for such a long time that clinicians are familiar with its normal values and in most instances can adequately estimate GFR for a particular patient with a certain serum creatinine. For cystatin C, however, there is so little experience that only few will know what GFR accompanies each cystatin C level. Secondly, as cystatin C is not routinely measured, cystatin $\mathrm{C}$ measurement is relatively expensive, especially if it should replace creatinine as a (daily) assessment of renal function [42]. On the other hand, several other markers that have comparable or more expensive costs to determine have made it into clinical practice in cardiology, including Troponins and $\mathrm{N}$-terminal brain natriuretic peptide. It will therefore take a change of mind from clinicians and researches to eventually replace serum creatinine with cystatin $\mathrm{C}$ in clinical practice, once future studies will provide more solid information on its routine use as point estimate and measure of changes in GFR.

\section{Glomerular permeability}

The previously mentioned markers give an estimate of GFR, the ability of the kidney to clear a certain amount of blood from the waste substances of metabolism. However, besides a reduction in filtration capabilities or even in the presence of preserved GFR, glomerular leakage may develop when glomerular capillary damage occurs. In these circumstances, larger than normal molecules enter the ultrafiltrate of which albumin is the most important one. When the leakage of albumin exceeds the tubular capacity of reabsorption, it appears in the urine in abnormal amounts.

\section{Albuminuria}

In patients with diabetes, hypertension, and chronic kidney disease, micro (30-300 mg/gram creatinine) and macroalbuminuria ( $>300 \mathrm{mg} / \mathrm{gram}$ creatinine) are commonly observed [43-45]. Importantly, albuminuria has been advocated as an important therapeutic target in patients with chronic kidney disease. Even independent of blood pressure, albuminuria is considered to be an important target for therapy, although strong evidence to support this is lacking. Even so, in CKD patients with diabetes, the degree of reduction in albuminuria was strongly correlated with cardiovascular outcome and, more importantly, incident HF [46]. The pathophysiology of albuminuria in general is considered to be related to endothelial dysfunction, increased intraglomerular pressure, and atherosclerosis [47]. Importantly, its pathophysiology, therefore, differs considerably from that of decreased GFR [48]. On the other hand, there are suggestions that albuminuria in HF may be associated with impaired renal perfusion and increased venous congestion, in analogy to decreased GFR [49-53]. These two entities define the clinical syndrome of HF, and therefore, it is surprising that only recently data on the prevalence and prognostic information on albuminuria and proteinuria in HF has been published. Van der Wal et al. were the first to show that albuminuria was present in $32 \%$ of patients with $\mathrm{HF}$, compared with $10 \%$ of an age and gender-matched healthy population [54]. In large sub studies of the CHARM and GISSI-HF trial, micro and macro-albuminuria were not only prevalent, but also associated with a strongly increased mortality rate $[55,56]$. This was even apparent in patients without decreased GFR, which may suggest that either albuminuria may be a very early sign of renal damage/ insufficiency as it has been reported in the general population, or that different mechanisms may contribute to reduced GFR and increased albumin excretion. For example, in general population studies, albuminuria was strongly related with the presence of diabetes and hypertension and might, therefore, be a reflection of comorbid organ dysfunction in HF [57]. These substudies assessed albuminuria in morning spot urine. In a substudy of the Val-HEFT, dipstick-positive proteinuria (rather than albuminuria) was infrequent, but still associated with impaired clinical outcome [58]. However, proteinuria as assessed by dipstick is a less precise, qualitative, rather than quantitative measurement and is therefore less sensitive and inaccurate estimate of high normal, micro or macroalbuminuria.

Importantly, both CHARM and GISSI-HF studies failed to show a significant reduction in albuminuria with either angiotensin receptor blockade or statin treatment. It is therefore unlikely that albuminuria may be useful as a primary target for therapy in patients with HF. However, albuminuria may serve as marker of prognosis in patients with $\mathrm{HF}$ and as a predictor of $\mathrm{HF}$ in patients without cardiac dysfunction, even when GFR is normal.

\section{Tubulointerstitial damage}

Nephrologists increasingly use markers that represent tubulointerstitial injury to provide a more appropriate estimation of "renal function". Although most markers 
have not made it into clinical practice yet, first results in HF patients look promising

\section{$\mathrm{N}$-acetyl-beta-D-glucosaminidase (NAG)}

NAG is a lysosomal enzyme that is formed in the proximal tubule and shed into the urine in response to tubular injury. It has been extensively studied in experimental and clinical settings and is a sensitive marker of proximal tubular damage in renal disease, but also after cardiopulmonary bypass grafting and diabetic nephropathy [59-61]. NAG is a prominent predictor of the occurrence of AKI or WRF [60, 62]. In CHF, urinary NAG levels are strongly elevated compared to age and gender-matched controls [63]. Interestingly, lower renal blood flow was associated with elevated NAG levels, indicating that tubulointerstitial damage may develop as a result of decreased renal perfusion, potentially by a decreased cardiac output [63]. Furthermore, higher NAG levels were associated with poorer clinical outcome in this group of patients with HF, independent of GFR. On the other hand, higher levels of NAG are also found in various other conditions, such as urinary tract infections, which may limit specificity [64]. Therefore, future research is needed in both acute and chronic HF to further establish the place of NAG as a renal tubular marker.

\section{Kidney injury molecule 1 (KIM-1)}

KIM-1 is a transmembrane protein that cannot be found in urine in normal situations. However, after hypoxic tubular injury, proximal tubule epithelial cells express KIM-1 at extremely high levels, which can reach up to 1000 -fold [65]. In experimental and clinical renal disease, KIM-1 urine levels reflect the extent of tubulointerstitial levels [66]. KIM-1 expression in biopsies of renal tissues in response to tubulointerstitial damage is primarily located at the proximal tubular epithelial cells and is predominantly present in areas of early fibrosis [67]. In children undergoing cardiopulmonary bypass grafting, KIM-1 was superior to NAG in predicting the occurrence of AKI after surgery [68]. The increase in both markers occurred almost $24 \mathrm{~h}$ before a rise in serum creatinine was apparent. KIM-1 (and NAG) may, therefore, possess properties related to the extent of (chronic) tubulointerstitial damage, but may also accurately and early predict those patients that are at increased risk of developing a deterioration in renal function. Urinary KIM-1 levels decrease in response to anti-hypertensive treatment with a combination of either thiazides, a low salt diet or angiotensin receptor blockade, and the reduction in KIM-1 was correlated with a reduction in proteinuria [69]. Of note, in animal experiments, the changes in urinary levels of KIM-1 during renoprotective intervention reflected the changes in tubulointerstitial
KIM-1 expression, suggesting that changes in urinary KIM-1 levels will have the potential to monitor the course and response to the intervention of tubulointerstitial damage [70]. As discussed earlier, albuminuria may also exist in chronic HF. Higher protein loading of the tubule may have a direct damaging effect on the tubular epithelium [69]. This can, therefore, be a different pathophysiologic pathway by which tubular damage and thereby higher urinary KIM-1 expression may develop. Clinical data on KIM-1 expression in chronic HF is limited. We recently found that urinary KIM-1 levels were strongly increased in patients with stable chronic HF and only mildly impaired GFR [63]. In fact, even in patients with normal GFR, urinary KIM-1 levels were strongly increased in comparison with matched control [63]. Importantly, urinary KIM-1 levels at a single point in time predicted outcome in these patients, independent of GFR. These results further acknowledge the prevalence ánd prognostic importance of tubulointerstitial damage in chronic HF and the ability of KIM-1 to identify high risk individuals. To date, no study evaluated KIM-1 expression in the setting of acute (decompensated) HF or evaluated the ability of KIM-1 to predict worsening of renal function in HF. As KIM-1 is predominantly expressed in response to ischemic tubular damage, especially the setting of acute HF, KIM-1 may be of clinical importance in this setting, although studies are still lacking. Although urinary KIM-1 is highly sensitive to (proximal) tubulointerstitial damage, it lacks specificity in the presence of other (chronic) comorbid organ dysfunction. For instance, KIM-1 levels are also increased in patients with hypertension and diabetic nephropathy [67]. As these patients may have a high risk for the development of HF, the baseline expression of KIM-1 in urine may be biased in such conditions.

\section{Neutrophil gelatinase-associated lipocalin (NGAL)}

NGAL is a small $(21 \mathrm{kD})$ protein that is normally detectable in serum as it is secreted in low amounts in lung, kidney, trachea, stomach, and colon [71]. Because of its small molecular weight, it is freely filtered through the glomerulus and completely reabsorbed in the tubules [71]. NGAL can be measured in plasma or urine. In normal situations, urine and plasma levels are low. Plasma NGAL levels are less specific for (acute) renal disease, as higher levels are also found in inflammation, sepsis, or cancer [71]. Urine levels are much less affected by these situations, since the NGAL that appears in the urine is secreted only from the tubules (plasma NGAL is filtered and totally reabsorbed) [71, 72]. In AKI, both plasma and urine NGAL rise strongly, and therefore, the relative contribution of nonrenal origins of NGAL is considered negligible. In response to tubulointerstitial damage, however, both serum 
and urinary concentrations may rise op to a 1000-fold and high concentrations of NGAL are expressed in urine, which mostly comes from production in the distal nephron (loop of Henley and collecting ducts) [71-73]. Urinary NGAL may, therefore, reflect occurrence of ischemic tubular injury in more distal parts of the nephron. However, high levels of NGAL in urine (and serum) have also been observed during proximal tubular injury, indicating that the site-specific increase in NGAL may be more complex [74]. NGAL measurements may be clinically useful as higher levels of NGAL are prominent predictors of the occurrence of AKI or WRF. In a landmark paper, Mishra et al. showed that higher NGAL serum and urine levels were able to predict the occurrence of AKI with remarkable specificity and sensitivity [73]. Importantly, similar to KIM-1 and $\mathrm{NAG}$, the rise in NGAL levels preceded the rise in serum creatinine by over $24 \mathrm{~h}$. Interestingly, administration of NGAL in experimental setting of acute ischemic renal injury attenuated tubular injury, suggesting a possible therapeutic role for NGAL by protecting against tubulointerstitial injury by inducing re-epithelialization [75]. Recent reports have studied the relationship between NGAL and WRF on outcome in acute HF. Higher plasma NGAL levels were found to predict the occurrence of WRF in patients admitted with acute HF [76]. A different study showed that higher plasma NGAL levels were related to a poorer clinical outcome [77]. In chronic HF, urinary NGAL levels are strongly increased in comparison with matched controls [78]. However, NGAL levels did not predict outcome in this group of CHF patients, in contrast to both NAG and KIM-1 [63]. Considering the lack of specificity of NGAL in the setting of chronic instead of acute renal failure, the acute rather than the chronic HF patient population may be a more suitable setting for the clinical implementation of NGAL.

\section{Interleukin 18 (IL-18)}

IL-18 is a proinflammatory cytokine that is quickly and highly upregulated in response to AKI in various situations [79]. It is one of the many proinflammatory cytokines, but IL-18 is particularly interesting given it possible role in mediation of ischemic renal failure [80]. IL-18 is detectable in urine after AKI and a sensitive predictor of AKI in the setting of cardiopulmonary bypass grafting [80]. In a comparative analysis, IL-18 levels preceded the rise in creatinine, but the rise in IL-18 was slower compared to the rise in NGAL [80]. Importantly, as a proinflammatory cytokine, IL-18 levels are also strongly increased in inflammatory conditions, such as arthritis and sepsis [81]. This limits the specificity of IL-18 in the setting of mixed AKI and pronounced inflammation. Some studies have investigated the role of IL-18 as a proinflammatory cytokine in ischemic heart disease. In a small study, plasma IL-18 levels were increased in patients with $\mathrm{HF}$, and those who survived had lower baseline plasma IL-18 levels [82]. Interestingly, this study found increased activity of IL-18 in human myocardium of failing hearts, which may suggest that IL-18 has pathophysiologic role in the setting of HF. IL-18 also predicts outcome in ischemic heart disease and, as such, was a predictor of the incidence of HF [83]. No studies have investigated the ability of IL-18 to predict AKI/WRF in the setting of HF.

Fatty acid-binding protein (FABP)

FABPs are proteins that bind selectively to free fatty acids. There are numerous different FABPs that have tissuespecific expression, which include the liver, heart, and brain [84]. Of these, liver FABP, (L-FABP or FABP-1) and heart FABP (H-FABP or FABP-3) have been associated with impaired renal function [85]. Both proteins are thought to play a role in the energy metabolism of the large amounts of energy consuming renal tubules. FABP-1 is exclusively found in the proximal tubules, whereas FABP-3 is localized in the distal tubules [86]. In response to ischemic injury, FABP-1 and FABP-3 are shed into the urine and detectable as sensitive and specific biomarkers of AKI. FABP-1 may even outperform NGAL and KIM-1 in AKI [87]. In an animal model, FABP-1 was superior to NAG in predicting AKI [39]. Further observations suggest that urinary FABP-1 levels are increased in response to hypoxia induced by impaired peritubular capillary blood flow in the kidney, a situation which is likely to exist in a low perfusion state such as HF [86]. FABP-3 levels may predict outcome in $\mathrm{HF}$, but the ability to predict AKI has not yet been studied [88].

\section{Conclusions}

The interaction between heart failure and renal impairment is not static, but comprises of dynamic changes in volume status, inflammatory response, neurohormonal activation and changes in renal function, by natural course, or in relation to therapy. These changes may be quick and substantial, but may also be slow and subtle. Finding the right marker to predict renal function in all of these situations may be impossible, but new markers are emerging that seem to perform better than serum creatinine alone. Some of these markers may give a good representation of GFR, such as cystatin C, BUN, while others give information on glomerular permeability (albuminuria) or tubulointerstitial damage (NAG, KIM-1, NGAL, and FABP). Importantly, the latter group (including IL-18) represents markers that may also predict acute changes in renal function, even 
before changes in creatinine occur. These markers are therefore suitable candidates as markers of treatment effect and as possible targets for therapy. New randomized clinical trials should, therefore, include measurement of these markers and possibly target these markers to preserve or even improve renal function in patients with HF.

Conflicts of interest DJVV reports having received consultancy fees from Biosite (Inverness Medical), manufacturer of NGAL test kits.

Open Access This article is distributed under the terms of the Creative Commons Attribution Noncommercial License which permits any noncommercial use, distribution, and reproduction in any medium, provided the original author(s) and source are credited.

\section{References}

1. Damman K, Jaarsma T, Voors AA, Navis G, Hillege HL, van Veldhuisen DJ (2009) Both in- and out-hospital worsening of renal function predict outcome in patients with heart failure: results from the coordinating study evaluating outcome of advising and counseling in heart failure $(\mathrm{COACH})$. Eur J Heart Fail 11:847-854

2. Hillege HL, Girbes AR, de Kam PJ, Boomsma F, de Zeeuw D, Charlesworth A, Hampton JR, van Veldhuisen DJ (2000) Renal function, neurohormonal activation, and survival in patients with chronic heart failure. Circulation 102:203-210

3. Vaz Perez A, Otawa K, Zimmermann AV, Stockburger M, Muller-Werdan U, Werdan K, Schmidt HB, Ince H, Rauchhaus M (2010) The impact of impaired renal function on mortality in patients with acutely decompensated chronic heart failure. Eur J Heart Fail 12:122-128

4. Damman K, Navis G, Voors AA, Asselbergs FW, Smilde TD, Cleland JG, van Veldhuisen DJ, Hillege HL (2007) Worsening renal function and prognosis in heart failure: systematic review and meta-analysis. J Card Fail 13:599-608

5. Metra M, Nodari S, Parrinello G, Bordonali T, Bugatti S, Danesi R, Fontanella B, Lombardi C, Milani P, Verzura G, Cotter G, Dittrich H, Massie BM, Dei Cas L (2008) Worsening renal function in patients hospitalised for acute heart failure: clinical implications and prognostic significance. Eur J Heart Fail 10: 188-195

6. Hata N, Yokoyama S, Shinada T, Kobayashi N, Shirakabe A, Tomita K, Kitamura M, Kurihara O, Takahashi Y (2010) Acute kidney injury and outcomes in acute decompensated heart failure: evaluation of the RIFLE criteria in an acutely ill heart failure population. Eur J Heart Fail 12:32-37

7. Ronco C, McCullough P, Anker SD, Anand I, Aspromonte N, Bagshaw SM, Bellomo R, Berl T, Bobek I, Cruz DN, Daliento L, Davenport A, Haapio M, Hillege H, House AA, Katz N, Maisel A, Mankad S, Zanco P, Mebazaa A, Palazzuoli A, Ronco F, Shaw A, Sheinfeld G, Soni S, Vescovo G, Zamperetti N, Ponikowski P (2010) Cardio-renal syndromes: report from the consensus conference of the acute dialysis quality initiative. Eur Heart J 31:703-711

8. Smilde TD, van Veldhuisen DJ, Navis G, Voors AA, Hillege HL (2006) Drawbacks and prognostic value of formulas estimating renal function in patients with chronic heart failure and systolic dysfunction. Circulation 114:1572-1580

9. Dittrich HC, Gupta DK, Hack TC, Dowling T, Callahan J, Thomson S (2007) The effect of KW-3902, an adenosine A1 receptor antagonist, on renal function and renal plasma flow in ambulatory patients with heart failure and renal impairment. J Card Fail 13:609-617

10. Levey AS, Coresh J, Greene T, Stevens LA, Zhang YL, Hendriksen S, Kusek JW, Van LF (2006) Using standardized serum creatinine values in the modification of diet in renal disease study equation for estimating glomerular filtration rate. Ann Intern Med 145:247-254

11. Smith GL, Shlipak MG, Havranek EP, Masoudi FA, McClellan WM, Foody JM, Rathore SS, Krumholz HM (2005) Race and renal impairment in heart failure: mortality in blacks versus whites. Circulation 111:1270-1277

12. Akhter MW, Aronson D, Bitar F, Khan S, Singh H, Singh RP, Burger AJ, Elkayam U (2004) Effect of elevated admission serum creatinine and its worsening on outcome in hospitalized patients with decompensated heart failure. Am J Cardiol 94:957-960

13. Levey AS, Bosch JP, Lewis JB, Greene T, Rogers N, Roth D (1999) A more accurate method to estimate glomerular filtration rate from serum creatinine: a new prediction equation. Modification of diet in renal disease study group. Ann Intern Med 130:461-470

14. Miller BF, Winkler AW (1938) The renal excretion of endogenous creatinine in man. Comparison with exogenous creatinine and inulin. J Clin Invest 17:31-40

15. Ix JH, Wassel CL, Stevens L, Beck GJ, Froissart M, Navis GJ, Rodby R, Schmid CH, Torres V, Zhang Y, Greene T, Levey AS (2011) Equations to estimate creatinine excretion rate: the CKD epidemiology collaboration. CJASN 6:184-191

16. Dries DL, Exner DV, Domanski MJ, Greenberg B, Stevenson LW (2000) The prognostic implications of renal insufficiency in asymptomatic and symptomatic patients with left ventricular systolic dysfunction. J Am Coll Cardiol 35:681-689

17. Smith GL, Lichtman JH, Bracken MB, Shlipak MG, Phillips CO, DiCapua P, Krumholz HM (2006) Renal impairment and outcomes in heart failure: systematic review and meta-analysis. J Am Coll Cardiol 47:1987-1996

18. Stevens LA, Schmid CH, Greene T, Zhang YL, Beck GJ, Froissart M, Hamm LL, Lewis JB, Mauer M, Navis GJ, Steffes MW, Eggers PW, Coresh J, Levey AS (2010) Comparative performance of the CKD epidemiology collaboration (CKD-EPI) and the modification of diet in renal disease (MDRD) study equations for estimating GFR levels above $60 \mathrm{~mL} / \mathrm{min} / 1.73 \mathrm{~m} 2$. Am J Kidney Dis 56:486-495

19. Aronson D, Mittleman MA, Burger AJ (2004) Elevated blood urea nitrogen level as a predictor of mortality in patients admitted for decompensated heart failure. Am J Med 116:466-473

20. Cauthen CA, Lipinski MJ, Abbate A, Appleton D, Nusca A, Varma A, Goudreau E, Cowley MJ, Vetrovec GW (2008) Relation of blood urea nitrogen to long-term mortality in patients with heart failure. Am J Cardiol 101:1643-1647

21. Filippatos G, Rossi J, Lloyd-Jones DM, Stough WG, Ouyang J, Shin DD, O'connor C, Adams KF, Orlandi C, Gheorghiade M (2007) Prognostic value of blood urea nitrogen in patients hospitalized with worsening heart failure: insights from the acute and chronic therapeutic impact of a vasopressin antagonist in chronic heart failure (ACTIV in CHF) study. J Card Fail 13:360-364

22. Lin HJ, Chao CL, Chien KL, Ho YL, Lee CM, Lin YH, Wu YW, Hsu RB, Chou NK, Wang SS, Chen CY, Chen MF (2009) Elevated blood urea nitrogen-to-creatinine ratio increased the risk of hospitalization and all-cause death in patients with chronic heart failure. Clin Res Cardiol 98:487-492

23. Gotsman I, Zwas D, Planer D, Admon D, Lotan C, Keren A (2010) The significance of serum urea and renal function in patients with heart failure. Medicine (Baltimore) 89:197-203

24. Heywood JT, Elatre W, Pai RG, Fabbri S, Huiskes B (2005) Simple clinical criteria to determine the prognosis of heart failure. J Cardiovasc Pharmacol Ther 10:173-180 
25. Lee DS, Austin PC, Rouleau JL, Liu PP, Naimark D, Tu JV (2003) Predicting mortality among patients hospitalized for heart failure: derivation and validation of a clinical model. JAMA 290:2581-2587

26. Shenkman HJ, Zareba W, Bisognano JD (2007) Comparison of prognostic significance of amino-terminal pro-brain natriuretic peptide versus blood urea nitrogen for predicting events in patients hospitalized for heart failure. Am J Cardiol 99:1143-1145

27. Klein L, Massie BM, Leimberger JD, O’Connor CM, Pina IL, Adams KF Jr, Califf RM, Gheorghiade M (2008) Admission or changes in renal function during hospitalization for worsening heart failure predict postdischarge survival: results from the outcomes of a prospective trial of intravenous milrinone for exacerbations of chronic heart failure (OPTIME-CHF). Circ Heart Fail 1:25-33

28. Schrier RW (2008) Blood urea nitrogen and serum creatinine: not married in heart failure. Circ Heart Fail 1:2-5

29. Laterza OF, Price CP, Scott MG (2002) Cystatin C: an improved estimator of glomerular filtration rate? Clin Chem 48:699-707

30. Dharnidharka VR, Kwon C, Stevens G (2002) Serum cystatin C is superior to serum creatinine as a marker of kidney function: a meta-analysis. Am J Kidney Dis 40:221-226

31. de Boer I, Katz R, Cao JJ, Fried LF, Kestenbaum B, Mukamal K, Rifkin DE, Sarnak MJ, Shlipak MG, Siscovick DS (2009) Cystatin $\mathrm{C}$, albuminuria, and mortality among older adults with diabetes. Diabetes Care 32:1833-1838

32. Shlipak MG, Sarnak MJ, Katz R, Fried LF, Seliger SL, Newman AB, Siscovick DS, Stehman-Breen C (2005) Cystatin C and the risk of death and cardiovascular events among elderly persons. N Engl J Med 352:2049-2060

33. Shlipak MG, Katz R, Fried LF, Jenny NS, Stehman-Breen CO, Newman AB, Siscovick D, Psaty BM, Sarnak MJ (2005) Cystatin-C and mortality in elderly persons with heart failure. J Am Coll Cardiol 45:268-271

34. Arimoto T, Takeishi Y, Niizeki T, Takabatake N, Okuyama H, Fukui A, Tachibana H, Nozaki N, Hirono O, Tsunoda $\mathrm{Y}$, Miyashita T, Shishido T, Takahashi H, Koyama Y, Kubota I (2005) Cystatin C, a novel measure of renal function, is an independent predictor of cardiac events in patients with heart failure. J Card Fail 11:595-601

35. Lassus J, Harjola VP, Sund R, Siirila-Waris K, Melin J, Peuhkurinen K, Pulkki K, Nieminen MS (2007) Prognostic value of cystatin $\mathrm{C}$ in acute heart failure in relation to other markers of renal function and NT-proBNP. Eur Heart J 28:1841-1847

36. Hoek FJ, Kemperman FA, Krediet RT (2003) A comparison between cystatin $\mathrm{C}$, plasma creatinine and the Cockcroft and Gault formula for the estimation of glomerular filtration rate. Nephrol Dial Transplant 18:2024-2031

37. Keevil BG, Kilpatrick ES, Nichols SP, Maylor PW (1998) Biological variation of cystatin C: implications for the assessment of glomerular filtration rate. Clin Chem 44:1535-1539

38. Tidman M, Sjostrom P, Jones I (2008) A comparison of GFR estimating formulae based upon s-cystatin $\mathrm{C}$ and s-creatinine and a combination of the two. Nephrol Dial Transplant 23:154-160

39. Newman DJ, Thakkar H, Edwards RG, Wilkie M, White T, Grubb AO, Price CP (1995) Serum cystatin C measured by automated immunoassay: a more sensitive marker of changes in GFR than serum creatinine. Kidney Int 47:312-318

40. Okura T, Jotoku M, Irita J, Enomoto D, Nagao T, Desilva VR, Yamane S, Pei Z, Kojima S, Hamano Y, Mashiba S, Kurata M, Miyoshi KI, Higaki J (2010) Association between cystatin C and inflammation in patients with essential hypertension. Clin Exp Nephrol 14:584-588

41. Singh D, Whooley MA, Ix JH, Ali S, Shlipak MG (2007) Association of cystatin C and estimated GFR with inflammatory biomarkers: the heart and soul study. Nephrol Dial Transplant 22:1087-1092

42. Filler G, Bokenkamp A, Hofmann W, Le BT, Martinez-Bru C, Grubb A (2005) Cystatin C as a marker of GFR-history, indications, and future research. Clin Biochem 38:1-8

43. Agewall S, Wikstrand J, Ljungman S, Fagerberg B (1997) Usefulness of microalbuminuria in predicting cardiovascular mortality in treated hypertensive men with and without diabetes mellitus. Risk factor intervention study group. Am J Cardiol 80:164-169

44. Brantsma AH, Bakker SJ, Hillege HL, de ZD, de Jong PE, Gansevoort RT (2008) Cardiovascular and renal outcome in subjects with K/DOQI stage 1-3 chronic kidney disease: the importance of urinary albumin excretion. Nephrol Dial Transplant 23:3851-3858

45. Mogensen CE (1984) Microalbuminuria predicts clinical proteinuria and early mortality in maturity-onset diabetes. $\mathrm{N}$ Engl $\mathrm{J}$ Med 310:356-360

46. de Zeeuw D, Remuzzi G, Parving HH, Keane WF, Zhang Z, Shahinfar S, Snapinn S, Cooper ME, Mitch WE, Brenner BM (2004) Albuminuria, a therapeutic target for cardiovascular protection in type 2 diabetic patients with nephropathy. Circulation 110:921-927

47. Comper WD, Hilliard LM, Nikolic-Paterson DJ, Russo LM (2008) Disease-dependent mechanisms of albuminuria. Am J Physiol Renal Physiol 295:F1589-F1600

48. Damman K, Hillege HL, van Veldhuisen DJ (2009) Albuminuria in heart failure: a CHARMing new risk factor? Lancet 374:506-508

49. Smilde TD, Damman K, van der HP, Navis G, Westenbrink BD, Voors AA, Boomsma F, van Veldhuisen DJ, Hillege HL (2009) Differential associations between renal function and "modifiable" risk factors in patients with chronic heart failure. Clin Res Cardiol 98:121-129

50. Wegria R, Capeci NE, Blumenthal MR, Kornfeld P, Hays DR, Elias RA, Hilton JG (1955) The pathogenesis of proteinuria in the acutely congested kidney. J Clin Invest 34:737-743

51. Damman K, Navis G, Smilde TD, Voors AA, van der BW, van Veldhuisen DJ, Hillege HL (2007) Decreased cardiac output, venous congestion and the association with renal impairment in patients with cardiac dysfunction. Eur J Heart Fail 9:872-878

52. Damman K, van DV, Navis G, Voors AA, van Veldhuisen DJ, Hillege HL (2009) Increased central venous pressure is associated with impaired renal function and mortality in a broad spectrum of patients with cardiovascular disease. J Am Coll Cardiol 53: 582-588

53. Damman K, Voors AA, Hillege HL, Navis G, Lechat P, van Veldhuisen DJ, Dargie HJ (2010) Congestion in chronic systolic heart failure is related to renal dysfunction and increased mortality. Eur J Heart Fail 12:974-982

54. van de Wal RM, Asselbergs FW, Plokker HW, Smilde TD, Lok D, van Veldhuisen DJ, van Gilst WH, Voors AA (2005) High prevalence of microalbuminuria in chronic heart failure patients. J Card Fail 11:602-606

55. Jackson CE, Solomon SD, Gerstein HC, Zetterstrand S, Olofsson B, Michelson EL, Granger CB, Swedberg K, Pfeffer MA, Yusuf S, McMurray JJ (2009) Albuminuria in chronic heart failure: prevalence and prognostic importance. Lancet 374:543-550

56. Masson S, Latini R, Milani V, Moretti L, Rossi MG, Carbonieri E, Frisinghelli A, Minneci C, Valisi M, Maggioni AP, Marchioli R, Tognoni G, Tavazzi L (2010) Prevalence and prognostic value of elevated urinary albumin excretion in patients with chronic heart failure: data from the GISSI-heart failure trial. Circ Heart Fail 3:65-72

57. Hillege HL, Fidler V, Diercks GF, van Gilst WH, de Zeeuw D, van Veldhuisen DJ, Gans RO, Janssen WM, Grobbee DE, de Jong PE (2002) Urinary albumin excretion predicts cardiovascular and 
noncardiovascular mortality in general population. Circulation 106:1777-1782

58. Anand IS, Bishu K, Rector TS, Ishani A, Kuskowski MA, Cohn JN (2009) Proteinuria, chronic kidney disease, and the effect of an angiotensin receptor blocker in addition to an angiotensinconverting enzyme inhibitor in patients with moderate to severe heart failure. Circulation 120:1577-1584

59. Bazzi C, Petrini C, Rizza V, Arrigo G, Napodano P, Paparella M, D'Amico G (2002) Urinary N-acetyl-beta-glucosaminidase excretion is a marker of tubular cell dysfunction and a predictor of outcome in primary glomerulonephritis. Nephrol Dial Transplant 17:1890-1896

60. Liangos O, Perianayagam MC, Vaidya VS, Han WK, Wald R, Tighiouart H, MacKinnon RW, Li L, Balakrishnan VS, Pereira BJ, Bonventre JV, Jaber BL (2007) Urinary N-acetyl-beta-(D)glucosaminidase activity and kidney injury molecule-1 level are associated with adverse outcomes in acute renal failure. J Am Soc Nephrol 18:904-912

61. Wellwood JM, Ellis BG, Price RG, Hammond K, Thompson AE, Jones NF (1975) Urinary N-acetyl-beta-D-glucosaminidase activities in patients with renal disease. Br Med J 3:408-411

62. Westhuyzen J, Endre ZH, Reece G, Reith DM, Saltissi D, Morgan TJ (2003) Measurement of tubular enzymuria facilitates early detection of acute renal impairment in the intensive care unit. Nephrol Dial Transplant 18:543-551

63. Damman K, van Veldhuisen DJ, Navis G, Vaidya VS, Smilde TD, Westenbrink BD, Bonventre JV, Voors AA, Hillege HL (2010) Tubular damage in chronic systolic heart failure is associated with reduced survival independent of glomerular filtration rate. Heart 96:1297-1302

64. Mohkam M, Karimi A, Habibian S, Sharifian M (2008) Urinary $\mathrm{N}$-acetyl-beta-D-glucosaminidase as a diagnostic marker of acute pyelonephritis in children. Iran J Kidney Dis 2:24-28

65. Han WK, Bailly V, Abichandani R, Thadhani R, Bonventre JV (2002) Kidney injury molecule-1 (KIM-1): a novel biomarker for human renal proximal tubule injury. Kidney Int 62:237-244

66. Vaidya VS, Ramirez V, Ichimura T, Bobadilla NA, Bonventre JV (2006) Urinary kidney injury molecule-1: a sensitive quantitative biomarker for early detection of kidney tubular injury. Am J Physiol Renal Physiol 290:F517-F529

67. van Timmeren MM, van den Heuvel MC, Bailly V, Bakker SJ, van Goor H, Stegeman CA (2007) Tubular kidney injury molecule-1 (KIM-1) in human renal disease. J Pathol 212:209-217

68. Han WK, Waikar SS, Johnson A, Betensky RA, Dent CL, Devarajan P, Bonventre JV (2008) Urinary biomarkers in the early diagnosis of acute kidney injury. Kidney Int 73:863-869

69. Waanders F, Vaidya VS, van Goor H, Leuvenink H, Damman K, Hamming I, Bonventre JV, Vogt L, Navis G (2009) Effect of renin-angiotensin-aldosterone system inhibition, dietary sodium restriction, and/or diuretics on urinary kidney injury molecule 1 excretion in nondiabetic proteinuric kidney disease: a post hoc analysis of a randomized controlled trial. Am J Kidney Dis 53:16-25

70. Kramer AB, van Timmeren MM, Schuurs TA, Vaidya VS, Bonventre JV, van GH, Navis G (2009) Reduction of proteinuria in adriamycin-induced nephropathy is associated with reduction of renal kidney injury molecule (Kim-1) over time. Am J Physiol Renal Physiol 296:F1136-F1145

71. Schmidt-Ott KM, Mori K, Li JY, Kalandadze A, Cohen DJ, Devarajan P, Barasch J (2007) Dual action of neutrophil gelatinase-associated lipocalin. J Am Soc Nephrol 18:407-413

72. Mori K, Lee HT, Rapoport D, Drexler IR, Foster K, Yang J, Schmidt-Ott KM, Chen X, Li JY, Weiss S, Mishra J, Cheema FH, Markowitz G, Suganami T, Sawai K, Mukoyama M, Kunis C, D'Agati V, Devarajan P, Barasch J (2005) Endocytic delivery of lipocalin-siderophore-iron complex rescues the kidney from ischemia-reperfusion injury. J Clin Invest 115:610-621

73. Mishra J, Dent C, Tarabishi R, Mitsnefes MM, Ma Q, Kelly C, Ruff SM, Zahedi K, Shao M, Bean J, Mori K, Barasch J, Devarajan P (2005) Neutrophil gelatinase-associated lipocalin (NGAL) as a biomarker for acute renal injury after cardiac surgery. Lancet 365:1231-1238

74. Mishra J, Ma Q, Prada A, Mitsnefes M, Zahedi K, Yang J, Barasch J, Devarajan P (2003) Identification of neutrophil gelatinase-associated lipocalin as a novel early urinary biomarker for ischemic renal injury. J Am Soc Nephrol 14:2534-2543

75. Mishra J, Mori K, Ma Q, Kelly C, Yang J, Mitsnefes M, Barasch J, Devarajan P (2004) Amelioration of ischemic acute renal injury by neutrophil gelatinase-associated lipocalin. J Am Soc Nephrol 15:3073-3082

76. Aghel A, Shrestha K, Mullens W, Borowski A, Tang WH (2010) Serum neutrophil gelatinase-associated lipocalin (NGAL) in predicting worsening renal function in acute decompensated heart failure. J Card Fail 16:49-54

77. Bolignano D, Basile G, Parisi P, Coppolino G, Nicocia G, Buemi M (2009) Increased plasma neutrophil gelatinase-associated lipocalin levels predict mortality in elderly patients with chronic heart failure. Rejuvenation Res 12:7-14

78. Damman K, van Veldhuisen DJ, Navis G, Voors AA, Hillege HL (2008) Urinary neutrophil gelatinase associated lipocalin (NGAL), a marker of tubular damage, is increased in patients with chronic heart failure. Eur J Heart Fail 10:997-1000

79. Vaidya VS, Ferguson MA, Bonventre JV (2008) Biomarkers of acute kidney injury. Annu Rev Pharmacol Toxicol 48:463-493

80. Parikh CR, Mishra J, Thiessen-Philbrook H, Dursun B, Ma Q, Kelly C, Dent C, Devarajan P, Edelstein CL (2006) Urinary IL-18 is an early predictive biomarker of acute kidney injury after cardiac surgery. Kidney Int 70:199-203

81. Gracie JA, Robertson SE, McInnes IB (2003) Interleukin-18. J Leukoc Biol 73:213-224

82. Mallat Z, Heymes C, Corbaz A, Logeart D, Alouani S, CohenSolal A, Seidler T, Hasenfuss G, Chvatchko Y, Shah AM, Tedgui A (2004) Evidence for altered interleukin 18 (IL)-18 pathway in human heart failure. FASEB J 18:1752-1754

83. Hartford M, Wiklund O, Hulten LM, Persson A, Karlsson T, Herlitz J, Hulthe J, Caidahl K (2010) Interleukin-18 as a predictor of future events in patients with acute coronary syndromes. Arterioscler Thromb Vasc Biol 30:2039-2046

84. Veerkamp JH, Paulussen RJ, Peeters RA, Maatman RG, van Moerkerk HT, van Kuppevelt TH (1990) Detection, tissue distribution and (sub)cellular localization of fatty acid-binding protein types. Mol Cell Biochem 98:11-18

85. Maatman RG, van Kuppevelt TH, and Veerkamp JH (1991) Two types of fatty acid-binding protein in human kidney. Isolation, characterization and localization. Biochem J 273(Pt 3):759-766

86. Noiri E, Doi K, Negishi K, Tanaka T, Hamasaki Y, Fujita T, Portilla D, Sugaya T (2009) Urinary fatty acid-binding protein 1: an early predictive biomarker of kidney injury. Am J Physiol Renal Physiol 296:F669-F679

87. Ferguson MA, Vaidya VS, Waikar SS, Collings FB, Sunderland KE, Gioules CJ, Bonventre JV (2010) Urinary liver-type fatty acid-binding protein predicts adverse outcomes in acute kidney injury. Kidney Int 77:708-714

88. Niizeki $\mathrm{T}$, Takeishi $\mathrm{Y}$, Arimoto $\mathrm{T}$, Nozaki $\mathrm{N}$, Hirono $\mathrm{O}$, Watanabe T, Nitobe J, Miyashita T, Miyamoto T, Koyama Y, Kitahara T, Suzuki S, Sasaki T, Kubota I (2008) Persistently increased serum concentration of heart-type fatty acid-binding protein predicts adverse clinical outcomes in patients with chronic heart failure. Circ J 72:109-114 